\title{
PERSPEKTIF ISLAM TERHADAP PEMBERIAN SUSU FORMULA KEPADA ANAK
}

\section{Oleh: Rahmadanni Pohan \\ STAI Nurul Falah Air Molek \\ Email: rahmadannipohan@gmail.com}

Abstract: Tulisan ini mendeskripsikan pandangan Islam terhadap pemberian susu formula kepada anak, yang mana dianjurkan kepada setiap ibu untuk memberikan ASI kepada anaknya secara langsung. Kalaupun si lbu atau anak tersebut tidak dapat memberi atau menerima ASI yang dikarenakan beberapa faktor yang sesuai dengan syariat Islam, maka anak boleh diberikan susu formula dengan catatan tidak ditemukan lagi ibu susuan (Wanita lain yang diupahkan untuk menyusui anak), karena pemberian ASI pada anak merupakan bagian paling dasar bagi perkembangannya sehingga tumbuh secara alami. Merupakan suatu kebahagian dan kebanggaan bagi ibu dan anak yang memperoleh ASI sehingga terciptanya hubungan yang sangat erat pada perkembangan jiwa, mental dan spiritual si buah hati.

Kata Kunci: Anak, Islam, Susu Formula 


\title{
PERSPEKTIF ISLAM TERHADAP PEMBERIAN SUSU FORMULA KEPADA ANAK
}

\author{
Oleh: Rahmadanni Pohan \\ STAI Nurul Falah Air Molek \\ Email: rahmadannipohan@gmail.com
}

\section{Pendahuluan}

Anak adalah titipan Allah SWT yang sangat mulia kedudukannya. Penghargaan terhadap anak harus didasarkan kepada kesadaran bahwa anak adalah rahmat Allah SWT yang diamanatkan kepada manusia. Amanah ini wajib dilaksanakan dan dipelihara. Allah SWT telah mengungkapkan tentang kewajiban manusia menunaikan amanah Allah SWT yang dititpkan kepada manusia. ${ }^{1}$

Senada dengan hal di atas, Al-Ghazali mengatakan: "Anak adalah amanah orang tuanya, hatinya yang bersih adalah permata berharga nan murni, yang kosong dari setiap tulisan dan gambar. Hati itu siap menerima setiap tulisan dan cenderung pada setiap yang ia inginkan. Oleh karena itu, jika dibiasakan mengerjakan yang baik, lalu tumbuh di atas kebaikan itu maka bahagialah ia didunia dan akhirat, orang tuanya pun mendapat pahala bersama.".2

Wanita memiliki kelebihan yang tidak dimiliki kaum Adam. Saat menjadi ibu, seorang perempuan dapat hamil, melahirkan, dan menyusui anak-anaknya. Dengan kodratnya, perempuan bukan saja melahirkan anak-anak. Namun, kaum Hawa juga menjadi rahim peradaban. Islam mengatur salah satu kewajiban seorang ibu saat anaknya baru melahirkan, yakni menyusui. Dalam surat Al Baqarah ayat 233, yang berlafadzkan:

${ }^{1}$ Zaitun, Sosiologi Pendidikan, (Pekanbaru: Mahkota Riau, 2009), h. 139

${ }^{2}$ Dadang Sobar Ali, Akhlaquna, (Bandung: Pustaka Setia, 2006), h. 109

151 Jurnal Madania: Volume 9 : 2, 2019 (e-ISSN 2620-8210 | p-ISSN 2088-3226 


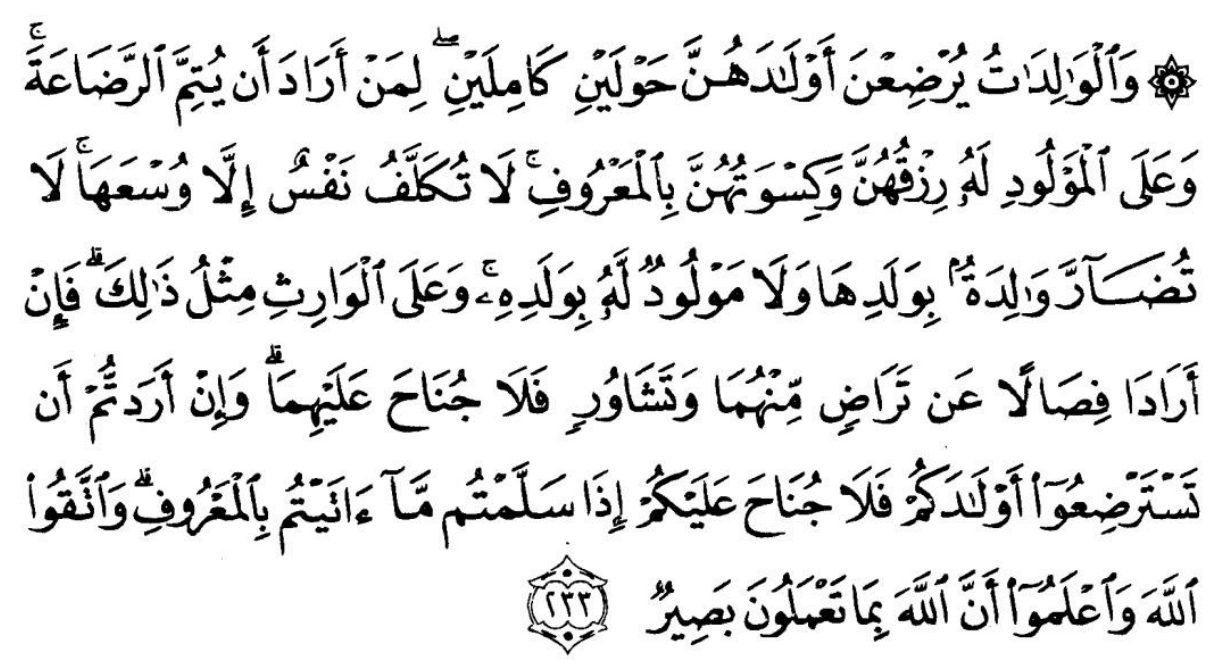

"Para ibu hendaklah menyusukan anak-anaknya selama dua tahun penuh, yaitu bagi yang ingin menyempurnakan penyusuan. Dan kewajiban ayah memberi makan dan pakaian kepada para ibu dengan cara ma'ruf. Seseorang tidak dibebani melainkan menurut kadar kesanggupannya. Janganlah seorang ibu menderita kesengsaraan karena anaknya dan seorang ayah karena anaknya, dan warispun berkewajiban demikian. Apabila keduanya ingin menyapih (sebelum dua tahun) dengan kerelaan keduanya dan permusyawaratan, maka tidak ada dosa atas keduanya. Dan jika kamu ingin anakmu disusukan oleh orang lain, maka tidak ada dosa bagimu apabila kamu memberikan pembayaran menurut yang patut. Bertakwalah kamu kepada Allah dan ketahuilah bahwa Allah Maha Melihat apa yang kamu kerjakan."

Air Susu Ibu (ASI) adalah minuman terbaik dan tak tergantikan bagi buah hati sejak lahir hingga awal 2 tahun kehidupannya. Golden liquid atau cairan emas ini merupakan modal awal membentuk generasi emas. Bahkan dalam Islam pun menyarankan untuk menyusui bayi hingga genap dua tahun umurnya.

Namun, pada kenyatannya, dengan semakin berkembangnya zaman dan emansipasi wanita yang tak lagi hanya mengurus dapur, sumur, dan kasur. Dapat mempengaruhi pergeseran pengasuhan anak. Tidak dapat dipungkiri lagi bahwa semakin tinggi pendidikan seorang wanita, maka semakin tinggi pula keinginannya untuk bekerja dalam mengimplementasikan ilmu yang dimilikinya. Sehingga kebutuhan 
signifikan anak mulai dikesampingkan. Seperti halnya Air Susu Ibu (ASI), yang mana selain memberikan ASI eksklusif maupun ASI dengan cara memerah dan menyimpannya di botol, ada juga ibu pekerja yang memilih susu formula. Menurut mereka cara ini adalah solusi bagi ibu yang kesulitan menyusui secara langsung karena tak punya kesempatan bersama anak setiap waktu. Padahal Sumber nutrisi ideal bagi bayi baru lahir hingga 2 tahun adalah air susu ibu (ASI).

Tidak hanya itu, tempat bekerja yang tidak mengakomodasi kebutuhan ibu menyusui menjadi salah satu faktor penyebab kegagalan menyusui. Para ibu pekerja terhalang oleh pendeknya cuti kerja, waktu istirahat, kurangnya dukungan tempat kerja, tidak cukup waktu, tidak ada ruangan memerah ASI, serta pertentangan antara mempertahankan prestasi kerja dan produksi ASI.

Kemudian, ada berbagai faktor yang menyebabkan seorang ibu memberikan susu formula kepada bayinya, yaitu dikarenakan Bayi bingung puting; Merasa ASI tidak cukup; Bayi mengalami galactosaemia; Ibu menjalani penanganan kanker payudara; Anak dehidrasi berat; Ibu mengkonsumsi obat sedatif atau yang mengandung radioactive iodine131; Mengalami kekerasan seksual, Bayi berhenti menyusui sendiri; Bayi mengalami phenylketonuria; Berhenti menyusui karena hamil; Bayinya anak adopsi; Mendapat saran yang salah; Ibu mengalami hypoplasia; lbu punya herpes simplex virus tipe 1 dan luka payudara; Tidak mendapat dukungan; Ibu menderita HIV; Bayi mengalami maple syrup urine disease; lbu menderita tuberkolosis aktif; Anak mengalami hypoglycaemia; Ibu punya luka sifilis pada payudara atau puting; serta Saat bayi baru lahir, pihak rumah sakit tidak langsung melakukan Inisiasi Menyusui Dini (IMD) kepada ibu dan bayi, akan tetapi memberikan susu formula kepada bayi yang baru lahir tersebut. IMD merupakan sebuah tahapan penting untuk memudahkan bayi memulai proses menyusui, dengan meletakkan bayi pada dada atau perut sang ibu sehingga secara alami dapat mencari sendiri sumber air susu ibu dan menyusu; Terjadinya pemisahan ruang antara ibu dan bayi yang baru lahir dikarenakan ibu mengalami pendarahan usai operasi Caesar, yang biasanya dalam dua hari pertama karena ia harus menjalani observasi selama 48 jam, sehingga setelah pulang dari rumah sakit, ada sebagian bayi yang kesulitan mencari puting karena lebih dulu kenal dot saat berada di rumah sakit. 


\section{Landasan Konseptual}

Kata 'menyusui' dalam Kamus Bahasa Indonesia diartikan dengan "memberikan air susu untuk diminum kepada bayi dari buah dada". ${ }^{3}$ Sedangkan dalam bahasa Al Quran, setidaknya ada dua term yang digunakan untuk menunjukkan pada kegiatan yang berkaitan dengan menyusui, yaitu:

Pertama, digunakan kata kerja radhi'a-yardha'u-radhâ'anradhâ'atan, untuk menunjukkan makna pada kegiatan menyusui. ${ }^{4}$ Secara bahasa kata al-radhâ'a bermakna menyusui, baik itu seorang perempuan atau pun binatang. Sedangkan secara istilah berarti menyampaikan air susu seorang perempuan kepada mulut bayi yang belum sampai usianya dua tahun. ${ }^{5}$ Kata ini terulang sebanyak 10 kali dengan berbagai derivasinya dalam Al Quran dan tersebar dalam 5 surat, yaitu: QS. AlBaqarah: 233, QS. Al-Nisâ': 23, QS. Al-Hajj: 2, Al-Qashash: 7 dan 12, QS. Al-Thalâq: 6 . $^{6}$

Kedua, digunakan juga istilah fishâl, yang merujuk pada makna menyapih. Secara bahasa fishâl bermakna fithâm, yaitu menceraikan. ${ }^{7}$ Maksud menceraikan disini yakni pemisahan anak dari susuan, atau pemisahan susuan karena anak terpisah dari asupan susu ibunya dan beralih kepada asupan makanan lainnya. Menurut gramatikal bahasanya, fishâl mengandung makna 'saling memisahkan', sebab anak terpisah dari ibunya, dan ibu pun terpisah dari anaknya, sehingga antara keduanya ada pemisahan. ${ }^{8}$ Kata ini terulang sebanyak 3 kali dalam Al Qur'an, yaitu pada QS. Al-Baqarah: 233, QS. Luqmân: 14 dan QS. AlAhqâf: $15 .^{9}$

\section{8), h. 1398}

${ }^{3}$ Tim Penyusun, Kamus Bahasa Indonesia, (Jakarta: Pusat Bahasa DEPDIKNAS,

${ }^{4}$ Mahmud Yunus, Kamus Arab-Indonesia, (Jakarta: Hidakarya Agung, 1990), Cet. VIII, h. 143. Lihat Juga Ibnu Manzhûr, Lisan Al-'Arab, Tt: Tp, h. 1660

5 'Abdurrahman Al Jazîriy, Kitab Al-Fiqh 'Alâ Madzâhibi Al-Arba'ah, Jilid. 4, (Beirut: Dar Al- Kutub Al-'Alamiyah, 2003), h. 23

6 Muhammad Fuâd Abd Al-Bâqiy, Mu'jam Al-Mufahras Li Alfâzh Al Qur'ân Al-Karîm, (Kairo: Dar Al-Hadits, 1346 H), h. 321

${ }^{7}$ Ibnu Manzhûr, Lisân Al-Arâb, thh, h. 3423

${ }^{8}$ Muhammad 'Ali Al-Shabuniy, Shafwat Al-Tafâsir, Jilid. 1, (Beirut: Dar Al-Qur'ân Al-Karîm, 1981/1401 H), h. 150

${ }^{9}$ Muhammad Fuâd Abd Al-Bâqiy, op.cit, h. 521

Rahmadanni Pohan: Prespektif Islami... 154 
Susu formula adalah jenis makanan yang halal untuk dikonsumsi, akan tetapi susu formula tidak Thayyibaa (tidak baik/tidak berkualitas/tidak bermutu) kalau diberikan kepada bayi yang baru dilahirkan, karena Air Susu Ibu (ASI) adalah satu-satunya jenis makanan yang $100 \%$ halal serta jauh lebih berkualitas untuk dikonsumsi oleh bayi yang baru lahir. Untuk itulah Allah SWT. menyerukan kepada para ibu yang baru melahirkan agar menyusui anak mereka hingga 2 tahun penuh bagi yang ingin menyempunakan masa menyusuinya.

Perintah memberikan asupan ASI pada bayi oleh Allah SWT dalam al-Qur'an bukan tanpa alasan, karena ternyata berdasarkan keterangan para ahli kesehatan dan gizi, bahwa ASI mengandung banyak manfaat bagi pertumbuhan bayi yang lebih baik jika dibandingkan dengan pemberian susu formula.

Anak merupakan kebanggaan sekaligus amanat yang mana orang tua harus berbangga karena dipercaya Allah Swt untuk memegang dan memelihara amanat-Nya. Memiliki anak berarti memiliki berkah dan rahmat yang tercurah dari Allah Swt. Dengan memilikinya banyak keuntungan yang dapat diperoleh orang tua. Nabi Muhammad Saw bersabda kepada kepada putrinya Fatimah RA: "Wahai Fatimah, tidaklah seorang wanita yang meminyaki rambut kepala anak - anaknya lalu menyisirnya dan mencucikan pakaiannya, melainkan Allah Swt menetapkan pahala baginya seperti pahala memberi makan kepada seribu orang yang kelaparan dan memberi pakaian kepada seribu orang yang telanjang."

Anak adalah semua penduduk yang berumur 18 tahun dan masih dalam kandungan serta belum matang fisik dan mental, yang memiliki hak untuk: Memperoleh identitas dari Negara (akta kelahiran); Anak diasuh oleh keluarga/alternatif untuk menanamkan kasih sayang, nilai positif agama dan norma social; Anak mendapat ASI, gizi, imunisasi dan jaminan kesehatan; Anak mendapat pendidikan, memanfaatkan waktu luang, beristirahat, bermain, berekreasi dan berkreasi; dan Anak mendapat perlindungan hukum secara khusus. ${ }^{10}$

${ }^{10}$ Undang - Undang Republik Indonesia Nomor 23 Tahun 2002 tentang Perlindungan Anak dan Nomor 35 Tahun 2014 tentang perubahan atas UU Nomor 23 tentang Perlindungan Anak, h. 87.

155 Jurnal Madania: Volume 9 : 2, 2019 (e-ISSN 2620-8210| p-ISSN 2088-3226 
Imam Nawawi RA. mengatakan ada 4 kebaikan yang didapat dari anak, yaitu: ${ }^{11}$ Dengan memiliki anak, berarti mengekalkan jenis manusia; Memperoleh cinta Rasulullah Saw dengan memperbanyak umatnya untuk dibanggakan oleh beliau pada hari kiamat; Mendapat keberkahan do'a anak shaleh; dan Mendapatkan syafaat dengan sebab matinya anak kecil, jika ia meninggal sebelum orang tuanya.

Anak merupakan rahasia dari orang tuanya, yang sejak awal perkembangannya berada dalam garis keturunan dari keagamaan orang tuanya. Jika orang tuanya muslim, otomatis anaknya menjadi muslim, dan jika merka kafir maka anknya akan menjadi kafir pula. Dalam HR. Muslim yang menyatakan bahwa: ${ }^{12}$

كل انسان تلاه امه على الفطرة وابواه بعد يهودانه وينصر انه ويمجسانه فان كانا مسلمين فمسلم "Setiap orang dilahirkan oleh ibunya atas dasar fitrah (potensi dasar untuk beragama), maka setelah itu orang tuanya mendidik menjadi beragama Yahudi dan Nasrani dan Majusi; Jika orang tua keduanya beragama Islam maka anaknya menjadi muslim (pula)."

Secara etimologis, kata Islam memiliki banyak pengertian yang antara lain adalah: Kata Islam, yang berasal dari kata kerja aslama, yaslimu dengan pengertian "menyerahkan diri, menyelamatkan diri, taat, patuh sepenuhnya dan tunduk." Kalau dilihat dari segi kata dasar salima yang mengandung pengertian "selamat, sejahtera, sentosa, bersih dan bebas dari cacat/cela." Sedangkan kalau dilihat dari kata dasar salam, maka akan berarti "damai, aman dan tentram."13 Serta Sullam yang berarti tangga (alat bantu untuk naik ke atas). ${ }^{14}$

Jadi dapat disimpulkan bahwa Islam adalah menempuh jalan keselamatan dengan jalan menyerahkan diri sepenuhnya kepada Allah SWT dan melaksanakan dengan penuh kepatuhan dan ketaatan akan segala ketentuan-ketentuan dan aturan-aturan yang ditetapkan oleh-Nya untuk mencapai kesejahteraan dan kesentausan hidup dengan penuh keamanan dan kedamaian.

${ }^{11}$ A. Abdurrahman Ahmad, Fadhilah Wanita Shalihah, (Cirebon: Pustaka Nabawi, Tth), h. 64 .

12 M. Arifin, Ilmu Pendidikan Islam: Tinjauan Teoretis Dan Praktis Berdasarkan Pendekatan Interdisipliner, (Jakarta: Bumi Aksara, 2008), h. 44.

13 Zuhairini, Filsafat Pendidikan Islam, (Jakarta: Bumi Aksara, 1991), h. 35

14 Jalaludin, Filsafat Pendidikan Islam: Telaah Sejarah dan Pemikirannya, (Jakarta: Kalam Mulia, 2011), h. 37 
Adanya keterkaitan Islam dengan kesehatan, yang mana telah kita ketahui bahwa Islam adalah agama yang kaffah dan telah menetapkan prinsip dalam menjaga keseimbangan tubuh manusia, seperti cara Islam menjaga kesehatan dengan menjaga kebersihan dan kearifan dalam memilih makanan yang halalan toyyiban.

\section{Lalu bagaimanakah pandangan Islam mengenai pemberian susu formula pada anak?}

ASI merupakan asupan terbaik bagi si anak, yang merupakan makanan sempurna yang mengandung berbagai zat makanan yang sangat diperlukan oleh tubuh makhluk hidup, sehingga metabolisme tubuhnya bisa berjalan lancar dan perkembangan badannya berlangsung dengan baik.

Rasulullah SAW menyebutkan bahwa dalam mimpi beliau melihat azab kepada kaum hawa: "Kemudian aku dibawa pergi. Tiba - tiba aku melihat para wanita yang buah dadanya dilahap oleh ular - ular. Aku bertanya, "Ada apa dengan mereka itu?" Dijawab: "Mereka adalah para wanita yang menghalangi anak - anak mereka dari air susu mereka." (Diriwayatkan oleh Ibnu Hibban, dan dinyatakan sahih oleh Al Allamah Al Albani dalam Shahihul Mawarid No. 1509).

Ancaman hadis ini berlaku, ketika seorang ibu sengaja menghalangi anaknya untuk mendapatkan nutrisi dari ASI nya tanpa alasan yang dibenarkan. Sementara jika sang ibu tidak memungkinkan untuk menyusui anaknya, baik karena faktor yang ada pada ibu maupun pada si anak, tidak termasuk dalam ancaman hadis ini. Karena itu, tidak masalah jika anak diberi susu selain ASI ibunya. Islam membolehkan seseorang menyusukan anaknya kepada orang lain, dengan kesepakatan upah tertentu sebagaimana termaktub dalam QS. AlBaqarah: 233 dan QS. At-Thalaq: 6.

Syekh Bin Baz seorang ulama dari Arab Saudi dalam Majmu' Fatawa Lajnah Daimah 21/7, beliau mengfatwakan tidak haram menggunakan susu formula jika memenuhi dua syarat:

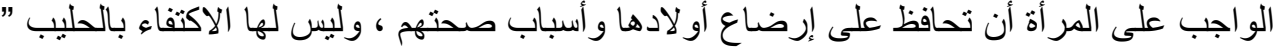

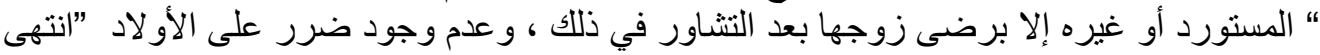
"Kewajiban seorang ibu untuk menjaga memberi ASI kepada anaknya dan kesehatannya. Seorang ibu tidak boleh mencukupkan dengan susu impor (formula) kecuali mendapat izin dari suaminya setelah 
bermusyawarah, dan tidak membahayakan kepada anaknya". Kemudian seorang ibu yang tidak menyusui anaknya namun diberi ASI oleh wanita lain berdasarkan firman Allah SWT dalam Surat At Thalaq ayat 6 diperbolehkan.

Dalam syariat kita dikenal istilah ibu susu, saudara sepersusuan, dan seterusnya. Bahkan karena menyusu kepada orang lain, bisa menyebabkan hubungan mahram, sebagaimana layaknya hubungan nasab. Sementara, mayoritas ulama menegaskan bahwa susuan bisa menyebabkan mahram, jika diberikan sebelum berusia dua tahun. Ini semua menunjukkan syariat membolehkan si anak untuk disusui orang lain di masa anak itu masih membutuhkan ASI ibunya, yaitu sebelum menginjak usia dua tahun.

Seorang ibu diizinkan tidak menyusui anaknya, dengan disusukan kepada wanita lain atau diberi susu formula. Namun tentu saja kebolehan ini tidak berlaku mutlak. Ada beberapa syarat dan ketentuan yang wajib diperhatikan, diantaranya:

1. Suami tidak mewajibkan sang istri untuk menyusui anaknya. Imam Ibnu Utsaimin mengatakan,

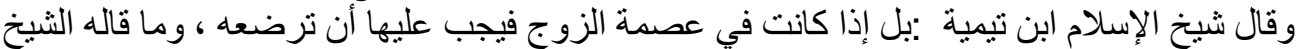





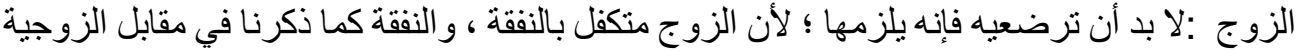

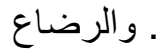

"Syaikhul Islam Ibnu taimiyah menegaskan, 'Bahkan jika si ibu masih menjadi istri dari suaminya, si ibu wajib menyusui anaknya' dan apa yang disampaikan oleh Syaikhul islam adalah pendapat yang benar. Kecuali jika si ibu dan si bapak merelakan untuk disusukan orang lain, hukumnya boleh. Namun jika suami menyuruh: 'Tidak boleh ada yang menyusuinya kecuali kamu' maka wajib bagi istri untuk menyusuinya. Meskipun ada orang lain yang mau menyusuinya atau meskipun si bayi mau mengkonsumsi susu formula. Selama suami menyuruh, 'Kamu harus menyusui anak ini' maka hukumnya wajib bagi istri. Karena suami berkewajiban menanggung nafkah, dan status nafkah - seperti yang telah kami jelaskan - merupakan timbal balik dari ikatan suami istri dan persusuan." (asy-Syarhul Mumthi', 13/517)

2. Si anak mau mengkonsumsi susu selain asi ibunya. Kewajiban orang tua adalah memberikan makanan bagi anaknya. Karena itu, jika ada 
anak yang tidak mau minum susu kecuali ASI ibunya, maka wajib bagi ibu untuk menyusuinya. Jika si ibu tetap tidak bersedia, maka dia berdosa karena dianggap menelantarkan anaknya. Al-Buhuti mengakan,

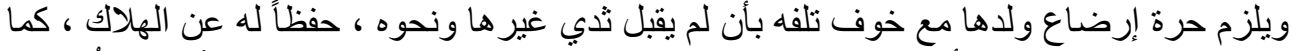

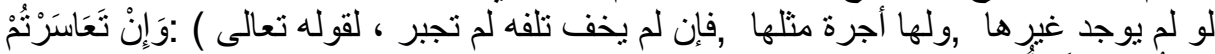

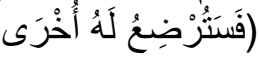

"Wajib bagi wanita merdeka untuk menyusui anaknya ketika dikhawatirkan anaknya terlantar karena tidak mau minum asi wanita lain atau susu lainnya. Dalam rangka menjaga anak ini dari kematian. Sebagaimana juga ketika tidak dijumpai wanita lain yang bersedia menyusuinya. Dan si istri berhak mendapatkan upah yang sewajarnya. Namun jika tidak dikhawatirkan si anak terlantar (karena masih mau minum susu lainnya) maka si istri tidak boleh dipaksa. Berdasarkan firman Allah (yang artinya), " jika kamu menemui kesulitan maka perempuan lain boleh menyusukan (anak itu) untuknya.." (Syarh Muntaha al-Iradat, 3:243)

Bahkan sebaliknya, jika ada anak yang justru muntah dengan ASI ibunya, sang suami tidak berhak memaksa istrinya untuk menyusui anaknya.

Inilah isyarat manfaat mengapa Allah swt memerintahkan para ibu untuk menyusui anak-anaknya hingga usia dua tahun, dan setelah masa itu, Allah membimbing untuk mulai menyapih anak, sebagaimana dijelaskan dalam surat Luqman: 14 dan Surat Al Ahqaf: 15.

Isyarat lain yang ditunjukkan adalah bahwa pendidikan anak pada rentang usia nol hingga dua tahun berada di pangkuan ibunya. Untuk itu ibu harus memaksimalkan pendidikan pada masa penting tersebut.

\section{Perbedaan antara ASI Eksklusif, ASI Perah dan Susu Formula:}

ASI merupakan makanan dan minuman pokok yang hanya boleh dikonsumsi oleh bayi yang baru lahir dan diberikan secara cepat/sedini mungkin setelah kelahiran (1 jam setelah lahir). ${ }^{15}$ Dan dianjurkan untuk memberikan ASI kepada bayi sesering mungkin sesuai keiinginan bayi (on demand), atau sesuai keiinginan ibu (jika payudara terasa

${ }^{15}$ Menyusui sejak awal kelahiran (1 jam setelah kelahiran) dikenal dengan Inisiasi Menyusui Dini (IMD). Kementrian Kesehatan RI, Buku Kesehatan Ibu dan Anak, (Jakarta: Kemesnkes, 1997), h. 34

159 Jurnal Madania: Volume 9 : 2, 2019 (e-ISSN 2620-8210 | p-ISSN 2088-3226 
penuh), atau sesuai kebutuhan bayi yaitu setiap dua-tiga jam (paling sedikit empat jam) sekali. ${ }^{16}$

Lebih lanjut, para ahli juga bersepakat bahwa memberikan ASI ekslusif kepada bayi sangat dianjurkan karena memiliki banyak sekali kebaikan, baik untuk bayi maupun untuk ibunya. ASI eksklusif adalah ASI yang diberikan kepada bayi sebagai asupan makanan dan minuman tanpa ditambah dengan jenis makanan atau minuman pendamping apapun. ${ }^{17}$ Pada awalnya pemberian ASI ekslusif dianjurkan sejak awal kelahiran hingga bayi berusia empat bulan, namun pada perkembangannya anjuran tersebut diperpanjang hingga enam bulan. ${ }^{18}$ Sebab komposisi ASI sampai dengan enam bulan tersebut sudah cukup untuk memenuhi gizi bayi meskipun tanpa makanan tambahan atau produk pendamping. Bayi yang disusui secara eksklusif sampai 6 bulan umumnya lebih sedikit menderita penyakit gastrointestinal, dan lebih sedikit mengalami gangguan pertumbuhan.

Pada tahapan selanjutnya, ASI diberikan kepada bayi dengan tambahan makanan lunak atau padat yang disebut dengan Makanan Pendamping ASI (MPASI) hingga mencapai usia dua tahun. ${ }^{19}$ Pemberian ASI dianjurkan hingga usia anak mencapai dua tahun sebab dua atau 1000 hari pertama kehidupan merupakan usia emas anak. Masa itulah yang memengaruhi anak menjadi sehat atau cerdas ketika dewasa nanti. Maka, gizi yang baik dan seimbang, termasuk pemberian ASI pada 1000 hari pertama kehidupan harus terpenuhi.

Beberapa kandungan penting dalam ASI:20

1. Kolostrum, yaitu cairan encer dan sering berwarna kuning atau jernih yang kaya zat anti infeksi (10-17 kali lebih banyak dari susu matang) dan protein. Kolostrum keluar pada hari pertama hingga hari ketiga. Kolostrum sangat berguna untuk membersihkan zat sisa dari saluran pencernaan bayi dan mempersiapkan untuk makanan yang akan datang. Kolostrum juga diketahui merupakan antibodi yang

${ }^{16}$ Ai Yeyeh Rukiyah dan Lia Yulianti, Asuhan Neonatus Bayi dan Balita, (Jakarta: CV. Trans Info Media, 2010), h. 66

17 Ari Sulistyawati, Buku Ajar Asuhan Kebidanan Pada Ibu Nifas, (Yogyakarta: CV. Andi Offset, 2009), h. 24

${ }^{18}$ Pusat Data dan Informasi Kementrian Kesehatan RI, Situasi dan Analisis ASI Eksklusif, (Jakarta: Kemenkes, 2014), h. 1

${ }^{19}$ Ai Yeyeh Rukiyah, dkk, op.cit, h. 67

${ }^{20}$ Ari Sulistyawati, op.cit, h. 20-22

Rahmadanni Pohan: Prespektif Islami... 160 
sangat baik bagi tubuh bayi karena dapat membunuh kuman dalam jumlah besar sehingga dapat mengurangi resiko kematian. ${ }^{21}$

2. Vitamin, ASI banyak mengandung vitamin baik yang dapat larut dalam lemak seperti vitamin $A, D, E$ dan $K$, maupun vitamin yang dapat larut dalam air seperti vitamin C, asam nicotinic, B12, B1, B2 dan B6.

3. Zat besi, meskipun ASI mengandung sedikit zat besi yaitu sekitar 0,5-1,0 mg/liter, namun bayi yang diberi ASI jarang terkena anemia.

4. Zat anti infeksi, ASI mengandung banyak anti infeksi terhadap berbagai penyakit, seperti penyakit saluran pernafasan atas, diare dan penyakit saluran pencernaan.

5. Laktoferin, terdapat banyak dalam ASI yaitu $1-6 \mathrm{mg} / \mathrm{ml}$, namun zat ini tidak terkandung dalam susu sapi. Zat ini berguna untuk menyerap zat besi dan daripencernaan sehingga terhindar dari suplai zat besi yang dibutuhkan oleh organisme patogenik.

6. Faktor bifidus, zat ini meningkatkan pertumbuhan bakteri baik dalam usus bayi (Lactobasilus Bifidus) yang melawan pertumbuhan bakteri patogen.

7. Lisozim, zat ini memiliki kekuatan beberapa ribu kai lebih tinggi disbanding yang terdapat dalam susu sapi. Zat ini berguna untuk melawan serangan E. Colidan Salmonela.

8. Taurin, merupakan asam amino terbanyak kedua dalam ASI dan tidak terdapat dalam susu sapi. Zat ini berfungsi untuk menutrisi otak.

Kualitas ASI perah baik yang pernah dibekukan atau dipasteurisasi menurun dibandingkan ASI langsung, tetapi tetap jauh lebih baik ASI perah dibandingkan susu formula. Komposisi ASI memiliki lebih dari 200 biofaktor (nutrisi yang terintegrasi dalam jumlah dan perbandingan yang tepat, sehingga menghasilkan nutrisi tumbuh kembang dan imunitas) sedangkan susu formula hanya sekitar 30-40 biofaktor. Penelitian menunjukkan bahwa IQ pada bayi yang diberi ASI memiliki IQ poin 4,3 lebih tinggi pada usia 18 bulan, 4-6 poin lebih tinggi pada usia 3 tahun, dan 8,3 poin lebih tinggi pada usia 8,5 tahun, dibandingkan bayi yang tidak diberi ASI. Dengan menyusi akan merangsang terbentuknya (EQ) pada anak serta meningkatkan kualitas hubungan antara ibu dan anak, sehingga anak mempunyai kecerdasan rohani yang optimum (SQ).

${ }^{21}$ KEMENKES RI, Profil Kesehatan Indonesia Tahun 2016, (Jakarta: KEMENKES RI, 2017), h. 138

161 Jurnal Madania: Volume 9 : 2, 2019 (e-ISSN 2620-8210 | p-ISSN 2088-3226 
Para ilmuwan berdasarkan penelitian yang mereka lakukan menegaskan, bahwa susu buatan mustahil dapat menggantikan fungsi susu murni atau ASI, karena kandungan yang dimiliki keduanya tidak bisa sama persis. Bakteriolog asal Jepang Riichi Sakazakii pada tahun 1980, mengemukakan bahwa makanan hasil olahan industri termasuk susu formula berpotensi menimbulkan virus Enterobacter Sakazakii (E. Sakazakii), terutama jika dikonsumsi oleh bayi baru lahir hingga usia 28 hari, bayi premature, bayi dengan berat badan lahir rendah (BBLR), bayi yang lahir dari ibu yang mengidap virus HIV dan bayi immunosupression (klainan antibodi). Jika bayi sudah trinfeksi E. Sakazakii 50\% silaporkan meninggal dalam waktu sati minggu setelah diagnosa, dan apabila bertahan hidup, maka akan mengalami komplikasi dan gangguan syaraf atau neorological disorder.

\section{Manfaat dari pemberian susu formula kepada anak:}

1. Lebih nyaman. Bayi yang diberi susu formula dapat diberi makan oleh siapa pun dan kapan pun.

2. Fleksibel. Ibu tidak harus selalu memompa ASI sesuai dengan jadwal kerja. Sebaliknya, Ibu dapat meninggalkan susu formula pada pengasuh atau penitipan bayi.

3. Bisa dilakukan siapa saja. Pasangan atau keluarga terdekat dapat membantu memberi susu untuk bayi kapan pun, entah itu di malam hari atau siang hari. Hal ini membuat proses pemberian susu ke bayi jadi ajang untuk berbagai pengalaman merasakan ikatan dengan bayi.

4. Penjadwalan pemberian susu lebih mudah. Susu formula tidak mudah dicerna secepat ASI, sehingga bayi yang diberi susu formula tidak perlu sering menyusu, terutama dalam beberapa bulan pertama.

5. Ibu tidak perlu khawatir tentang apa yang akan dimakan. Ibu yang menyusui mungkin harus menghindari beberapa jenis makanan tertentu yang tidak bisa ditolerir bayinya.

\section{Dampak negatif dari pemberian Susu Formula:}

1. Kurangnya kontak fisik antara ibu dan bayi. Bayi jadi tak memiliki momen khusus bersama ibunya.

2. Bayi yang diberi makan melalui botol berpeluang mengalami obesitas.

3. Praktik pemberian ASI ternyata juga berpengaruh pada pertumbuhan susunan gigi. Bayi yang disusui lebih mungkin terbebas penyakit 
karies. Karies merupakan kerusakan pada struktur jaringan keras gigi (email, dentin) karena asam yang dihasilkan oleh bakteri pada plak gigi. Kemungkinan cross-bite gigi atas dan gigi bawah tersusun berlawanan dari susunan normal yang tepat juga lebih rendah pada anak yang diberi ASI dibandingkan anak yang disusui lewat botol.

4. Dapat mengurangi sistem imunitas pada anak. Secara signifikan anak akan mengalami batuk dan flu.

\section{Manfaat memberikan ASI:}

1. Sehat, praktis dan tidak butuh biaya; Meningkatkan kekebalan alamiah pada bayi; Mencegah perdarahan pada ibu nifas; Menjalin kasih saying ibu dan bayi; dan Mencegah kanker payudara. ${ }^{22}$

2. Ibu yang menyusui anaknya memiliki keseimbangan hormon lebih baik. Sementara, bayinya dapat dua manfaat sekaligus, yakni kenyang dan nyaman.

3. Memberikan ASI secara langsung, lanjutnya, memberikan keuntungan tak hanya bagi bayi. Dampak itu juga baik buat ibu, yakni untuk menyeimbangkan hormon pasca-persalinan. Secara jangka panjang, menyusui berdampak pada kesehatan mental anak.

4. Bayi yang disusui secara langsung cenderung lebih aktif pada hari ketiga pasca-persalinan. Tak hanya itu, setelah pemberian ASI langsung selama 4-9 bulan, tingkat kecerdasan mereka juga lebih tinggi.

5. Salah satu dampak baik dari menyusui adalah mengajarkan insting "makan" kepada bayi. Dengan ASI langsung, bayi diberikan pilihan untuk berhenti makan saat merasa kenyang. Sementara itu, pemberian ASI lewat botol cenderung mendorong bayi menghabiskan isinya.

6. ASI mengandung nutrisi penting yang baik untuk tubuh. Pada ASI terdapat sistem kekebalan tubuh yang terkandung dalam proteinprotein seperti lactoferin dan $\lg A$ yang berfungsi melindungi bayi dari infeksi kuman-kuman seperti bakteri, virus maupun parasit. Pemberian ASI eksklusif 6 bulan dapat mengurangi angka kematian bayi yang disebabkan oleh penyakit seperti diare atau radang paru-paru serta membantu mempercepat proses penyembuhan.

7. ASI lebih mudah dicerna dibanding susu formula. Oleh karena itu, ASI dapat mengurangi risiko sembelit dan perut kembung pada bayi.

${ }^{22}$ Kementrian Kesehatan Republik Indonesia, Buku Kesehatan Ibu dan Anak, Jakarta: Kementrian Kesehatan dan JICA (Japan International Cooperation Agency), 1997, h. 34 
8. ASI dapat menurunkan risiko kematian bayi mendadak pada tahun pertama.

9. ASI dapat meningkatkan kecerdasan anak. Penelitian menunjukkan bahwa bayi yang minum ASI memiliki tingkat fungsi kognitif lebih tinggi.

10. ASI dapat mengurangi risiko anak terkena berbagai penyakit di kemudian hari. ASI diketahui dapat mengurangi risiko kelebihan berat badan, sakit asma, diabetes tipe 1 dan tipe 2, kolesterol tinggi, penyakit Hodgkin, leukemia, dan limfoma pada anak.

11. Wanita yang menyusui dapat mengurangi risiko kanker payudara, diabetes, penyakit jantung, osteoporosis, dan kanker ovarium. Namun jangan lupa bahwa alasan utama para ibu baru memilih untuk menyusui, yaitu pengalaman untuk merasakan ikatan yang indah dengan bayi Anda.

12. Secara psikologi, dengan menyusui dapat memberi pengaruh pada:

a. Psikologi pada ibu. Setelah melahirkan, ibu mengalami perubahan fisik dan fisiologis yang juga mengakibatkan adanya beberapa perubahan psikisnya. la mengalami stimulasi kegembiraan yang luar biasa, menjalani eksplorasi dan asimilasi terhadap bayinya, berada di bawah tekanan untuk dapat menyerap pembelajaran yang diperlukan tentang apa yang harus diketahui dan perawatan untuk bayinya. Begitu juga fenomena yang dikenal dengan post partum blues atau baby blues, yaitu sebuah sekuel umum pasca kelahiran - biasanya terjadi pada $70 \%$ wanita. Fenomena ini biasanya dimulai para beberapa hari setelah kelahiran dan berakhir setelah 10-14 hari. Karakteristik post partum blues melipui menangis, merasa letih pasca melahirkan, gelisah, perubahan alam perasaan, menarik diri, serta reaksi negatif terhadap bayi dan keluarga. Dan dengan menyusui secara langsung terutama sesaat pasca melahirkan (IMD) akan menurunkan tekanan tersebut dan memberikan rasa tenang pada jiwa sang ibu.

b. Psikologi pada anak. Sentuhan awal/ kontak kulit antara ibu dan bayi pada menit-menit pertama dan beberapa jam setelah kelahiran diketahui akan berpengaruh pada tumbuh kembang anak. Inilah yang dikenal dengan bounding attachment, yaitu peningkatan hubungan kasih sayang dengan keterkaitan orang tua dan bayi. Bounding attachment ini bersifat unik, spesifik dan bertahan lama. 
Dampak positifnya bagi psikologi anak adalah anak merasa dicintai, diperhatikan, mempercayai dan menumbuhkan sikap sosial sehingga anak merasa aman dan berani mengadakan eksplorasi. Ikatan ini akan terus-menerus bertambah kuat setiap kali ibu menyusui anaknya, sebab ketika menyusui tidak hanya terjadi kontak kulit tetapi juga kontak mata, dimana ibu dan anak saling pandang. Mendengar dan merespon suara antara orang tua dan anaknya. Selain itu dengan meyusui anak akan mengenali aroma susu ibunya. Kenyataan juga menunjukkan bahwa dengan menyusui, dapat memberi menenangkan anak yang dalam keadaan rewel. Tegasnya terjadi komunikasi yang baik antara anak dan orang tua yang baik untuk perkembangan psikologi anak.

\section{Penutup}

Allah SWT memerintahkan kepada para ibu untuk menyusui anakanaknya, dan memberi batas hingga dua tahun. Dengan ASI itulah anak dapat membentuk dirinya dari darah ibu. Darah ini kemudian beralih menjadi susu, dan susu itulah yang menjadi makanan bayi, yang mana dari ASI tersebutlah menjadi daging dalam diri anak. Pemberian ASI inilah yang akan membantu anak memulai kehidupannya dengan baik.

Seorang ibu sewaktu menyusui anak, ia tidak sekedar menyusui, tetapi dengan penuh perasaan kelembutan, kasih sayang dan belaian. Dengan demikian, perasaan sayang itulah yang akan tumbuh pada diri seorang anak, juga rasa cinta dan kebaikan.

Mengingat begitu pentingnya pemberian ASI bagi bayi sebab tidak ada susu atau minuman dan makanan apapun yang sepadan dengan kebaikan ASI. Bahkan bagi para ibu yang tidak dapat menyusui anaknya sendiri sebab alasan-alasan tertentu, di dalam AI Qur' an Allah SWT tidak menganjurkan para orang tua untuk memberikan makanan atau minuman lain sebagai pengganti ASI. Akan tetapi Allah swt membimbing agar orang tua dapat mencarikan perempuan lain untuk menyusukan anak-anak mereka. Meskipun mereka harus mengeluarkan biaya untuk upah.

Mayoritas ulama berpendapat bahwa perintah menyusui hukumnya adalah sunnah. Kecuali ternyata anak tidak dapat menyusu dari perempuan lain, atau ayah tidak mampu memberikan upah untuk perempuan lain untuk menyusukan anaknya, atau memang jika tidak dijumpai seorang perempuan yang siap menyusui. Alasan mengapa 
hukumnya menjadi sunnah, tidak lain karena didasarkan pada firman Allah dalam QS. Al-Thalâq: 6. Seandainya menyusui hukumnya wajib, niscaya syara' akan memaksa ibu supaya menyusui anaknya. Dengan dasar itulah, maka hukumnya menjadi sunnah, sebab air susu ibunyalah yang paling baik bagi anak dan kasih sayang ibu sendiri jauh lebih banyak.

Lain halnya dengan pemberian susu formula kepada anak. Pada dasarnya, keputusan untuk memberi susu formula untuk bayi biasanya didasarkan pada tingkat kenyamanan, kondisi fisik, serta gaya hidup. Namun, dalam hal ini apabila ibu memiliki alasan yang sesuai dengan syariat untuk tidak menyusui anaknya, alangkah baiknya menyusukan anaknya kepada ibu lain agar tetap mendapatkan nutrisi yang cukup, terawat dan dicintai dengan baik.

\section{Daftar Pustaka}

Al Jazîriy, 'Abdurrahman. Kitab Al-Fiqh 'Alâ Madzâhibi Al-Arba'ah, Jilid. 4, (Beirut: Dar Al- Kutub Al-'Alamiyah, 2003).

Ahmad, Abdul Abdurrahman. Fadhilah Wanita Shalihah, (Cirebon: Pustaka Nabawi, Tth).

Rukiyah, Ai Yeyeh dan Lia Yulianti. Asuhan Neonatus Bayi dan Balita, (Jakarta: CV. Trans Info Media, 2010).

Sulistyawati, Ari. Buku Ajar Asuhan Kebidanan Pada lbu Nifas, (Yogyakarta: CV. Andi Offset, 2009).

Ali, Dadang Sobar. Akhlaquna, (Bandung: Pustaka Setia, 2006).

Manzhur, Ibnu. Lisan Al-'Arab, Tt: Tp.

Jalaludin, Filsafat Pendidikan Islam: Telaah Sejarah dan Pemikirannya, (Jakarta: Kalam Mulia, 2011).

KEMENKES RI, Profil Kesehatan Indonesia Tahun 2016, (Jakarta: KEMENKES RI, 2017).

Kementrian Kesehatan Republik Indonesia, Buku Kesehatan Ibu dan Anak, Jakarta: Kementrian Kesehatan dan JICA (Japan International Cooperation Agency), 1997.

Arifin, M. IImu Pendidikan Islam: Tinjauan Teoretis Dan Praktis Berdasarkan Pendekatan Interdisipliner, (Jakarta: Bumi Aksara, 2008).

Yunus, Mahmud. Kamus Arab-Indonesia, (Jakarta: Hidakarya Agung, 
1990), Cet. VIII.

Menyusui sejak awal kelahiran (1 jam setelah kelahiran) dikenal dengan Inisiasi Menyusui Dini (IMD). Kementrian Kesehatan RI, Buku Kesehatan Ibu dan Anak, (Jakarta: Kemesnkes, 1997).

Al-Shabuniy, Muhammad 'Ali. Shafwat Al-Tafâsir, Jilid. 1, (Beirut: Dar Al-Qur'ân Al-Karîm, 1981/1401 H).

Al-Bâqiy, Muhammad Fuâd Abd. Mu'jam Al-Mufahras Li Alfâzh Al -Qur'ân Al-Karîm, (Kairo: Dar Al-Hadits, 1346 H).

Pusat Data dan Informasi Kementrian Kesehatan RI, Situasi dan Analisis ASI Eksklusif, (Jakarta: Kemenkes, 2014).

Tim Penyusun, Kamus Bahasa Indonesia, (Jakarta: Pusat Bahasa DEPDIKNAS, 2008).

Undang - Undang Republik Indonesia Nomor 23 Tahun 2002 tentang Perlindungan Anak dan Nomor 35 Tahun 2014 tentang perubahan atas UU Nomor 23 tentang Perlindungan Anak.

Zaitun, Sosiologi Pendidikan, (Pekanbaru: Mahkota Riau, 2009). Zuhairini, Filsafat Pendidikan Islam, (Jakarta: Bumi Aksara, 1991). 